УДК 339.924

\title{
НАПРЯМИ РОЗВИТКУ МЕДИЧНОГО ТУРИЗМУ В УКРАЇНІ ТА ЙОГО ВПЛИВ НА ЕКОНОМІКУ
}

\author{
Казакова Н.А., к.геогр.н., доцент, \\ Марушева А.А., к.ю.н., доцент, \\ Прав Ю.Г., к.е.н., доцент, \\ Гулаг А.О., магістр (ХНУ імені В.Н. Каразіна)
}

У сучасному, динамічному суспільстві туризм $\epsilon$ одним із основних видів міжнародної економічної діяльності, складною і комплексною сферою, що виявляє істотний вплив на структуру $i$ загальну ситуацію в світовій економіці. У зв 'язку з чим, сфера туризму надає стимулюючу дію на такі сектори економіки, як транспорт, зв'язок, торгівлю, будівництво, сільське господарство, виробництво товарів та послуг. На сьогодні стрімкого розвитку набув медичний туризм - виїзд населення за кордон з метою отримання медичних послуг. Украӥна має шанси стати одним із основних иентрів медичного туризму як на регіональному, так $i$ на міжнародному рівнях. Дослідженню впливу медичного туризму на економіку України та інтеграційні прочеси, які відбуваються сьогодні і присвячена дана стаття.

Ключові слова: міжнародний туризм, кордони, медицина, економіка.

\section{НАПРАВЛЕНИЯ РАЗВИТИЯ МЕДИЦИНСКОГО ТУРИЗМА В УКРАИНЕ И ЕГО ВЛИЯНИЕ НА ЭКОНОМИКУ}

\author{
Казакова Н.А., к.геогр.н., доцент, \\ Марушев А.А., к.ю.н., доцент, \\ Прав Ю.Г., к.э.н., доцент, \\ Гулаг А.А., магистр (ХНУ имени В.Н. Каразина)
}

В современном, динамично обществе туризм является одним из основных видов международной экономической деятельности, сложной и комплексной сферой, оказывающих существенное влияние на структуру и общую ситуачию в мировой экономике. Сфера туризма оказывает стимулирующее воздействие на такие секторы экономики, как транспорт, связь, торговлю, строительство, сельское хозяйство, производство товаров и услуг. Именно поэтому исследования современных тенденций в сфере туризма являются актуальными. Стремительное развитие приобрел медицинский туризм - выезд населения за гранииу с иелью получения медицинских услуг. Украина имеет шансы стать одним из основных ичентров медицинского туризма как на региональном, так и на международном уровнях. Исследованию влияния медицинского туризма на экономику Украины и интеграционные процессы, которые происходят сегодня и посвящена данная статья.

Ключевые слова: международный туризм, границы, медицина, экономика.

(C) Казакова Н.A.,

Марушева А.А.,

Прав Ю.Г.,

Вісник економіки транспорту і промисловості № 63, 2018

Гулаг А.О. 


\title{
DIRECTIONS FOR THE DEVELOPMENT OF MEDICAL TOURISM IN UKRAINE AND ITS EFFECTS ON THE ECONOMY
}

\author{
Kazakova N.A., candidate of geography, associate professor, \\ Maroushev A.A, Cand. Sci., Associate Professor, \\ Prav Yu.G., Candidate of Economic Sciences, Associate Professor, \\ Gulag A.A, master's degree (KNU named after VN Karazin)
}

In a modern, dynamic society, tourism is one of the main types of international economic activity, a complex and complex sphere that exerts a significant influence on the structure and overall situation in the world economy. The sphere of tourism has a stimulating effect on such sectors of the economy as transport, communications, trade, construction, agriculture, production of goods and services. That is why studies of current trends in tourism are relevant. Rapid development has acquired medical tourism - travel of the population abroad for the purpose of obtaining medical services. Although the phenomenon of medical tourism is not new. The integration of Ukraine in the field of medical tourism in the near future will occur mainly due to the departure of its citizens abroad. However, having significant opportunities to attract foreign patients and pursuing a rational policy in medicine, economics and tourism, Ukraine has a chance to become one of the main centers of medical tourism both at the regional and international levels. A well-known fact is the significant role of tourism in the modern world. In addition to recreational functions, this type of service creates conditions for inflow of financial resources (including foreign investments), promotes cultural exchange and provides job creation, while for some countries tourism is actually the only source of income. At the same time, as researchers point out, tourism is an important driving force for integration processes, ensuring interpenetration and exchange of financial and human resources. Although traditionally the main focus is tourism for recreation purposes, the situation has changed somewhat over the last 15 years. Rapid development has become medical tourism - the departure of the population abroad for the purpose of obtaining medical services.

Key words: international tourism, borders, medicine, economics.

Постановка

Загальновідомим фактом є значна роль туризму в сучасному світі. Окрім виконання рекреаційної функції, даний вид послуг створює умови для притоку фінансових ресурсів (у тому числі іноземних інвестицій), сприяє культурному обміну та забезпечує створення робочих місць, при цьому для ряду країн туризм є фактично єдиним джерелом доходів. Разом із тим, як зазначають дослідники, туризм $\epsilon$ важливою рушійною силою для інтеграційних процесів, забезпечуючи взаємопроникнення та взаємообмін фінансовими та людськими ресурсами. Хоча традиційно основним напрямом вважається туризм із метою відпочинку, за останні 15 років ситуація дещо змінилася. Стрімкого розвитку набув медичний туризм - виїзд населення за кордон 3 метою отримання медичних послуг.

Аналіз останніх досліджень i публікацій. Хоча явище медичного туризму не $\epsilon$ новим (одним із найперших прикладів відомих місць для лікування $\epsilon$ давньогрецькі храми Асклепія, збудовані ще до нашої ери), саме наприкінці 20 століття воно почало набувати найбільшого значення i ступеню поширеності. Варто відзначити, що, незважаючи на поточну економікополітичну ситуацію, Україна має значний потенціал розвитку в сфері медичного 
туризму. Окрім того, за даними зарубіжних інтернет-ресурсів, у 2008 році Україна займала сьоме місце у світі за кількістю прийнятих з-за кордону медичних туристів [1].

Основними чинниками, що впливають на розвиток медичного туризму у світі, є ціни на медичні послуги та їх доступність. Наприклад, операція шунтування в Сполучених Штатах Америки коштує 100 тис. доларів США, у той час як в Індії ця ж операція, яка проводитиметься у лікарні 3 найсучаснішим

коштуватиме всього 10 тис. доларів. Подорож до іншої країни 3 метою лікування може бути шляхом уникнути черги на операцію, наявність яких $\epsilon$ характерною для країн із централізованими державними системами охорони здоров'я (наприклад, Великобританія та Канада). Варто відзначити, що для більшості центрів медичного туризму характерною $є$ висока якість наданих послуг та наявність висококваліфікованого персоналу: велика кількість закладів має акредитацію таких організацій, як JointCommitteeInternational та ISO, аїх лікарський склад має престижну західну освіту [1,2].

Виділення невирішених частин загальної проблеми. Враховуючи прагнення України вийти на вищий рівень економічних та політичних відносин із рештою країн світу, треба визначити основні основні чинники впливу медичного туризму в Україні на ii інтеграційні процеси та перспективні напрямки розвитку медичного туризму як нового перспективного напряму розвитку, яке має ї велике значення для майбутнього економіки країни.

Мета статті. Виявлення основних напрямків розвитку медичного туризму, основних економічних та конкурентних засад впливу на економіку - являється метою даної статті.

Виклад основного матеріалу. Велику роль в медичному туризмі відіграє якість обслуговування. Для провідних центрів медичного туризму стандартом $\epsilon$ максимально дбайливе ставлення лікарів, медсестер та медперсоналу до пацієнтів. При цьому можливим $є$ більш тривалий строк перебування в лікарні під наглядом кваліфікованих лікарів, без переповнених лікарняних палат і черг. Метою медичного туризму також може бути лікування за методиками, які $\epsilon$ унікальними або які не $\epsilon$ доступними в країні проживання пацієнтів. В цьому контексті варто виділити альтернативні напрями медицини, такі як натуропатія, акупунктура та ін. Крім того, велика кількість передових сучасних лікареньзнаходиться у популярних туристичних центрах, що в багатьох випадках робить можливим поєднання лікувальних процедур та відпочинку, приваблюючи безліч людей з усього світу.

На даний момент Україна є одним iз перспективних центрів медичного туризму. По-перше, цьому сприяе вигідне географічне розташування країни, що полягає у наявності великої кількості транзитних транспортних шляхів, близькості до інших європейських країн та доступі до Чорного моря. По-друге, медичний персонал в українських лікувальних закладах має досить високу кваліфікацію. Беззаперечною перевагою України $\epsilon$ наявність великої кількості природних рекреаційних ресурсів. На території країни $\epsilon$ велика кількість джерел різноманітних за складом мінеральних вод, наявні джерела лікувальних грязей та озокериту, що доповнюється сприятливими кліматичними умовами. Окреме місце займає Карпатський регіон, значний рекреаційний потенціал якого зумовлений наявністю великих лісових масивів, значної кількості джерел мінеральних вод (особливо у Трускавці, Східниці та Моршині), джерел лікувальних грязей, а також сприятливий клімат. Як стверджує М. Мальська, наявна база природно-санаторної галузі дозволяє щорічно приймати до 8 мільйонів людей 
[3].

Проте наявність розвиненої санаторної бази $\epsilon$ не єдиною конкурентною перевагоюУкраїни на ринку медичного туризму. За оцінками спеціалізованих видань в Україні є понад 50 спеціалізованих медичних закладів із висококваліфікованим персоналом, які орієнтовані на надання послуг зарубіжним пацієнтам. За даними Української асоціації медичного туризму, основними напрямами медицини в Україні, що користуються попитом серед іноземних пацієнтів, є:

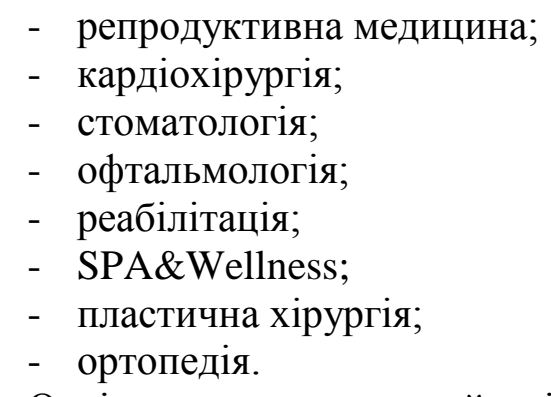

Окрім того, значний інтерес представляють напрями відновної медицини та лікування стовбуровими клітинами, яке $\epsilon$ одним із найбільш інноваційних та перспективних напрямів медицини. При цьому якість наданих медичних послуг є приблизно на одному рівні із зарубіжними клініками, в той час як вартість лікування в Україні $\epsilon$ щонайменше в 2 рази дешевшого, ніж за кордоном.

Як було зазначено вище, однією із значних конкурентних переваг України на міжнародному ринку медичних послуг $\epsilon$ низькі ціни на лікування. У таблиці 1 для порівняння наведено ціни на різні категорії та види поширених медичних послуг, а також витрати на проживання та транспорт в Україні, Румунії (яка межує 3 Україною та має схожий рівень економічного розвитку) та Франції (яка $\epsilon$ входить до «Великої сімки» передових держав світу) $[3,4]$.

Таблиияя 1

Порівняння витрат на лікування в Румунії, Франиії та Україні (у євро) [10,11]

\begin{tabular}{|l|l|l|l|}
\hline & Румунія & Франція & Україна \\
\hline Проживання & від 40 & від 70 & від 20 \\
\hline Транспортні витрати & 0,3 на 1 км & 1,5 на 1 км & 0,1 на 1 км \\
\hline Зубні імплантати & 450 & 850 & 400 \\
\hline Коронки & 170 & 800 & 135 \\
\hline Вініри & 250 & 600 & 200 \\
\hline Відбілювання зубів & 300 & 400 & 250 \\
\hline $\begin{array}{l}\text { Лазерна корекція } \\
\text { зору }\end{array}$ & 550 & 2000 & 700 \\
\hline Грудні імплантати & 3000 & 4500 & 4400 \\
\hline Ринопластика & 2500 & 4000 & 2000 \\
\hline Ліпосакція & 1100 за ділянку & 2500 за ділянку & 1300 за ділянку \\
\hline
\end{tabular}

Окрім

вищезазначених конкурентних переваг, суттєве значення для становлення України як центру медичного туризму є співробітництво із іншими державами та організаціями. Так, Міністерство охорони здоров'я України співпрацює із такими установами, як Всесвітня організація охорони здоров'я, Міжнародний Комітет Червоного Хреста, ЮНІСЕФ, ПРООН, Агентство США 3 міжнародного розвитку, Швейцарське бюро співробітництва та іншими. Міжнародне співробітництво здійснюється також і на нижчих рівнях: так, Науково-практичний центр профілактичної та клінічної медицини в рамках окремих наукових відділів співпрацюе із такими країнами, як Польща, Словаччина, Йорданія та країни СНД. Крім того, ведеться співробітництво 
на рівнях місцевих органів влади (наприклад, у 2012 році в рамках угоди між Вінницькою міською радою та Агентством Ізраїлю 3 розвитку міжнародного співробітництва (МАШАВ) було збудовано новий діагностичний центр у м. Вінниця). Як показує практика, діяльність України щодо співпраці 3 іншими державами та організаціями у сфері медицини є досить результативною. До України з метою отримання медичних послуг приїжджають громадяни таких країн, як Франція, Італія, США, Німеччина, Молдова та ін. Окрім того, в останні роки збільшився потік медичних туристів 3 арабських країн. Це зумовлено великою кількістю студентів медичних вишів та факультетів із цих країн, щодопомагає створити позитивний імідж української медицини в арабському світі [10].

Таким чином, на основі вказаних вище даних ми можемо стверджувати про наявність в України значних перспектив у сфері медичного туризму, що полягають у наявності санаторно-лікувальної бази, значного наукового потенціалу, природнокліматичних умов та економічній доцільності лікування. Наявність таких факторів розвитку зумовлює приплив іноземних громадян до України 3 метою отримання медичних послуг, що створює рух фінансових ресурсів та вкупі 3 міжнародною співпрацею між Україною, іншими державами та профільними організаціями створює умови для інтеграції України в міжнародний економічний простір як одного iз перспективних центрів медичного туризму. 3 метою оцінити перспективи розвитку галузі міжнародного медичного туризму в Україні пропонуємо провести розрахунки динаміки кількості в’”̈̈них та виїзних медичних туристів iз використанням графічного методу та методу тренд-аналізу.

Для розрахунків використаємо дані лише щодо туристів, які перетинали кордон України (з огляду на характер дослідження внутрішній медичний туризм розглядатися не буде). В якості досліджуваного періоду часу обираємо 2011-2017 роки 3 огляду на нерівномірність економічного розвитку України. Вихідні дані стосовно кількості закордонних туристів, які прибули в Україну, та українців, які відправилися за кордон 3 метою лікування, наведено у таблиці 2.

Таблиия 2

Кількість медичних туристів у 2011-2017 рр. [10,11]

\begin{tabular}{|l|l|l|l|l|l|l|l|}
\hline Рік & 2011 & 2012 & 2013 & 2014 & 2015 & 2016 & 2017 \\
\hline До України & 15544 & н/д & н/д & н/д & 2427 & 5913 & 3009 \\
\hline 3 України & 2908 & н/д & н/д & н/д & 1147 & 1469 & 9371 \\
\hline
\end{tabular}

Як можна побачити, в період з 2012 по 2014 pp. статистичні дані стосовно кількості медичних туристів відсутні, що обмежує можливості для розрахунків. В такому випадку ми вважаємо доцільним обрати тренд-аналіз в якості основного методу дослідження, оскільки він дозволяє абстрагуватися від впливу випадкових чинників. При цьому діапазон вихідних даних становитимуть дані за 2011-2017 рр. (відсутні дані на графіку позначатися не будуть), оскільки досліджуваний період
2015-2017 pp. є недостатньо значним для отримання достовірних даних, a ігнорування періоду з 2012 по 2014 рр. під час розрахунків призведе до спотворення кінцевих результатів. Разом із тим, дослідивши таблицю 2, можна побачити, що зміна значень досліджуваних показників є неоднорідною та, відповідно, наявний значний розкид значень даних. Можливою причиною такого характеру даних, на нашу думку, є зміна економікополітичного становища в Україні, 
особливо у період 2013-2014 pp., та іi тривалі наслідки. Таким чином, можна зробити припущення про наявність гетероскедастичності похибки, яка знижує точність результатів проведеного лінійного тренд-аналізу. Негативний вплив гетероскедастичності похибки на результати розрахунків полягає в тому, що вона знижує значення стандартних похибок i через це дає нам підстави вважати розраховані величини (наприклад, коефіцієнт детермінації $\mathrm{R}^{2}$, який грає велику роль при проведенні тренд-аналізу) статистично значущими, коли насправді вони такими можуть не бути. Відповідно, наявність гетероскедастичності може призвести до отримання помилкових результатів. Тому 3 метою забезпечити більшу точність, достовірність розрахунків, а також всебічний підхід до вирішення завдання в умовах нестачі даних, скористаємося різними методиками тренд-аналізу [10,11].

1) Лінійний тренд-аналіз. В даному випадку передбачається побудова прямої лінії, що описує динаміку значень величин.Результати наведені на рис. 1.

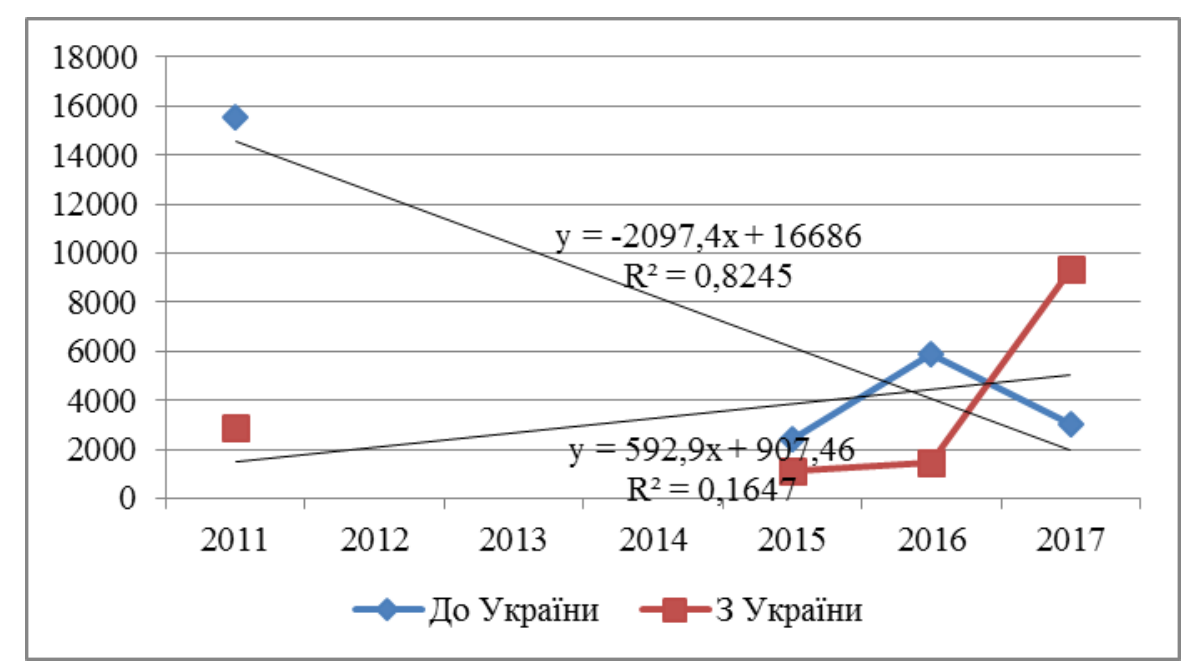

Рис. 1. Лінійний тренд-аналіз динаміки кількості медичних туристів до України та з України

Як видно із рис. 1, рух іноземних туристів до України має низхідну динаміку, що підтверджується від'ємним коефіцієнтом перед змінною $x$. Значення коефіцієнту достовірності апроксимації $R^{2}$ $\epsilon$ більшим за 0,7 , що може вказувати на високу ймовірність збереження даної тенденції в майбутньому. Динаміка значень кількості медичних туристів 3 України, як видно із рис. 1, є висхідною, проте низьке значення коефіцієнту $R^{2}$ при цій лінії тренду свідчить про низьку ступінь достовірності виявленої тенденції. Проте, як було зазначено вище, суттєвий розкид значень досліджуваних величин по координатній площині, відсутність статистичних даних за 2012-2014 роки та неоднорідний характер їх зміни у часі не дає нам змоги обмежитися отриманими в цьому випадку результатами. Тому скористаємося нелінійними моделями тренд-аналізу [6].

2) Логарифмічний тренд. Такий різновид лінії тренду представлений рівнянням виду $y(x)=a * \ln (x)+b$, де $x-$ значення на осі абсцис, $b$ - точка перетину лінії тренду із віссю ординат. Даний вид трендів використовується при роботі із рядами даних, для яких характерним $\epsilon$ різке зростання або спад на початку досліджуваного періоду із наступною стабілізацією (що $є$ характерним для деяких із наявних у нас даних).

Результати побудови лінії тренду зображені на рис. 2. 


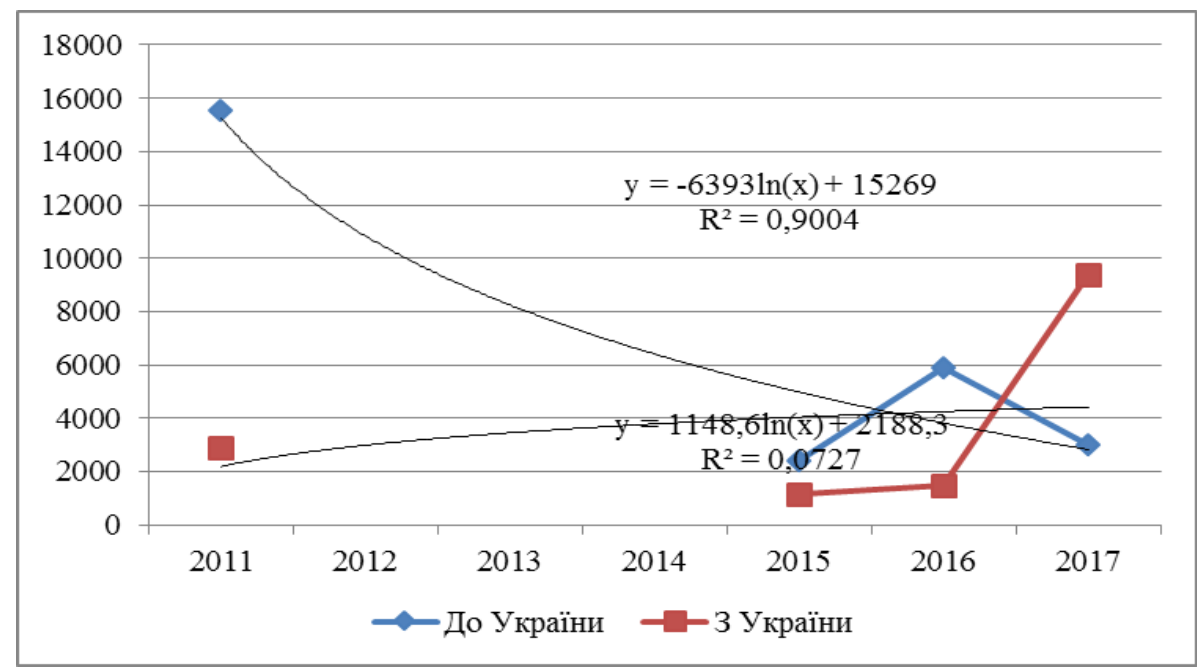

Рис. 2. Логарифмічний тренд-аналіз динаміки кількості медичних туристів до Украйни та з Украӥни

Як видно із рис. 2, характер отриманих ліній тренду є подібним до тих, які отримали при здійсненні лінійного тренд-аналізу. Динаміка значення туристського потоку до України $є$ низхідною із великим значенням коефіцієнту $R^{2}$, в той час як лінія тренду, що описує динаміку кількості туристів 3 України, які виїжджають на лікування за кордон, $\epsilon$ висхідною (коефіцієнт $R^{2}$ у цьому випадку також має низьке значення, що може вказувати на низьку достовірність даної тенденції).

3) Поліноміальний

тренд використовується для даних, значення яких поперемінно зростають та спадають (як можна побачити у табл.1, значення досліджуваних нами показників відповідають цим вимогам). За його допомогою можна проаналізувати масиви даних із одним або декількома максимумами або мінімумами. В нашому випадку використаємо поліноміальний тренд першого ступеню, який описується рівнянням $y=a x 2+b x+c$ і який дозволить нам визначити період, коли спостерігалося максимальне або мінімальне значення відповідного потоку осіб, що прибули до України або вибули 3 неї 3 метою лікування.

Результати обчислень наведені на рис. 3.

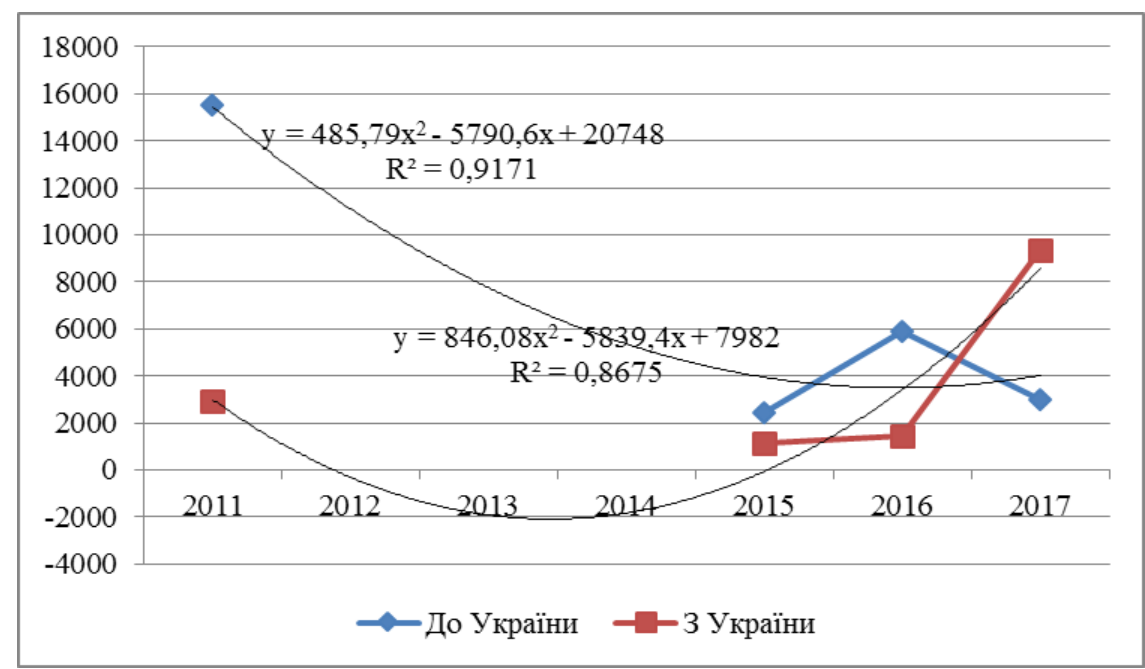

Рис. 3. Поліноміальний тренд-аналіз динаміки кількості медичних туристів до Украӥни та з України

Вісник економіки транспорту і промисловості № 63,2018 
При побудові поліноміальних коефіцієнт $R^{2}$ має високе значення (це трендів, як можна побачити на рис.3, може свідчити про тенденцію до отримали дещо інші, ніж при попередніх зростання кількісних значень як вхідного, спробах, результати. Динаміка кількісних так і вихідного потоків медичних туристів значень обох туристичних потоків, як можна побачити із рівнянь їх трендів, $\epsilon$ позитивною, причому в обох випадках у майбутньому).

4) Степеневий тренд. Результати тренд-аналізу зображено на рис. 4.

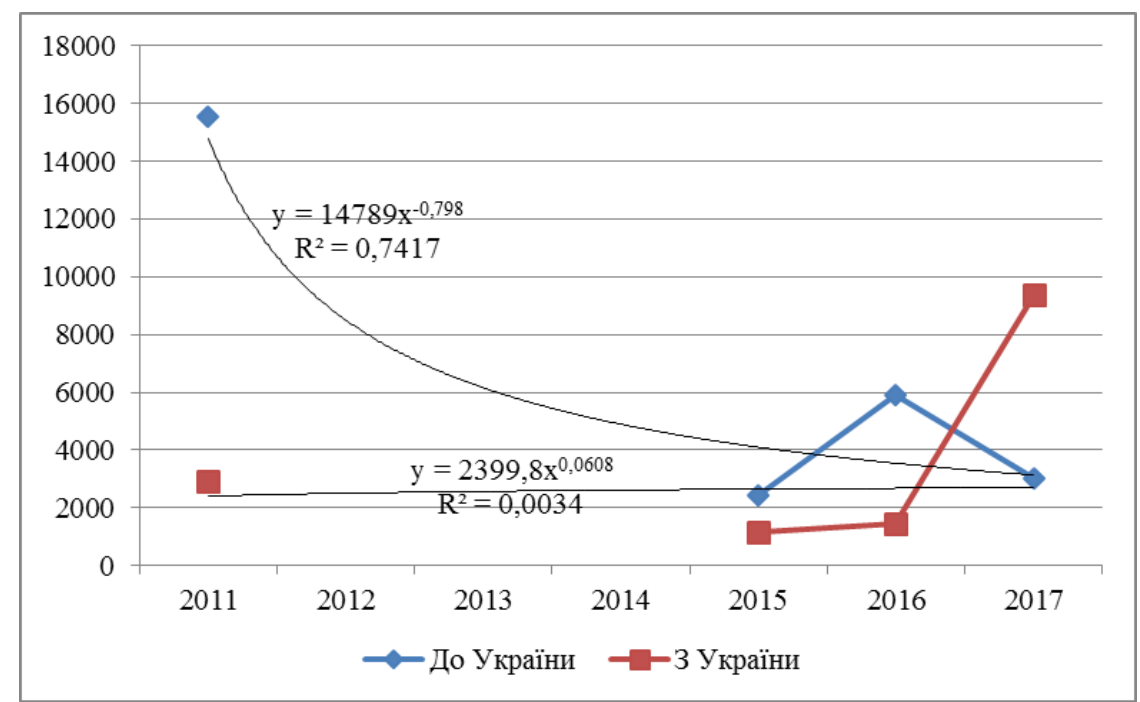

Рис. 4. Степеневий тренд-аналіз динаміки кількості медичних туристів до Украӥни та з України

За допомогою цього різновиду тренд-аналізу можна змоделювати декілька видів процесів, які характеризують досліджувані дані, а саме:

- ріст із сповільненням (приріст значень $y$ із збільшенням $x$ зменшується);

- ріст із пришвидшенням (приріст значень $y$ збільшується із ростом $x$ );

- падіння із сповільненням;

- падіння із пришвидшенням.

Проаналізувавши

характер отриманих ліній тренду, можна помітити, що в цілому вони $є$ подібними до результатів лінійного та логарифмічного тренд-аналізу, наведених вище, що виражається у характері ліній (низхідний для потоку туристів до України, висхідний - для кількості туристів 3 України) та значеннях коефіцієнту детермінації $R^{2}$ (Високе значення - для ряду даних «До
України», низьке - для ряду «З України»). Динаміка кількості туристів, що прибувають до України, характеризується скороченням їх кількості, причому темпи скорочення зменшуються із часом.

5) Експоненційний тренд. Даний вид тренд-аналізу застосовується, як правило, для даних, швидкість яких безперервно зростає.

Результати побудови експоненційного тренду наведені на рис. 5.

Як можна побачити на рис. 5, результати експоненційного тренд-аналізу $\epsilon$ подібними до результатів лінійного, логарифмічного та степеневого тренданалізу, що виявляється у схожості динаміки ліній тренду та значень коефіцієнтів детермінації для кожної 3 них. 


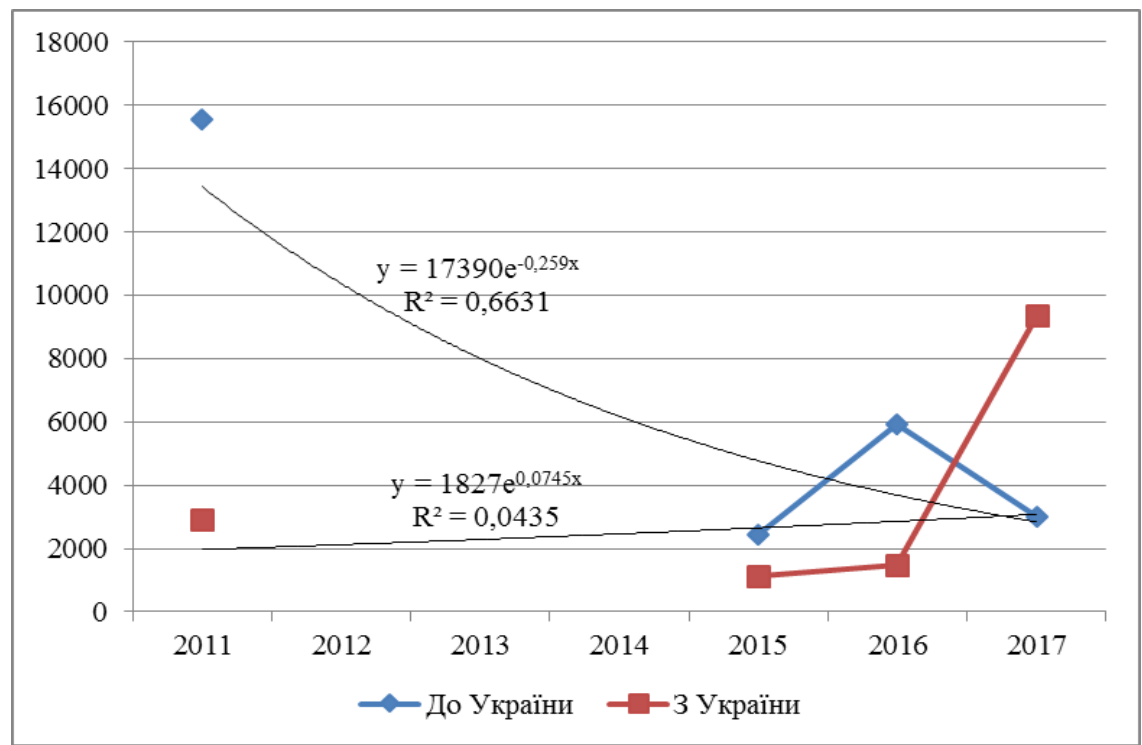

Рис. 5. Експоненційний тренд-аналіз динаміки кількості медичних туристів до України та з України

Порівнявши застосовані нами значення кількості туристів з України в варіанти тренд-аналізу, ми обрали період між 2012 та 2015 роками $\epsilon$ поліноміальний тренд-аналіз в якості від’ємними, що за природою досліджуваної основи для подальших досліджень, оскільки саме за його допомогою було знайдено достовірне значення коефіцієнту детермінації $R^{2}$ для обох досліджуваних туристичних потоків, а також тому, що отримані нами лінії тренду відображають ситуацію, близьку до реальності. Проявом цього, як можна побачити на рис. 3, є те, що мінімуми ліній трендів в даному випадку відносяться до періоду 2012-2014 pp. (статистичні дані за який відсутні) або розташовані близько до нього. Враховуючи економіко-політичну ситуацію, яка склалася в 2013-2015 pp. і яка мала негативні наслідки для розвитку туристичної галузі України та ії економіки в цілому, ми можемо зробити припущення про те, що скорочення обсягів туристичних потоків дійсно мало місце у вищезгаданий період [7].

Разом із тим, навіть результати проведеного поліноміального тренданалізу не є достатньо точними. Як видно на рис. 3 , лінія поліноміального тренду для значень кількості медичних туристів, що відбувають з України за кордон, перетинає вісь абсцис у точках, що відповідають 2012 та 2015 рокам (відповідно, орієнтовні величини є неможливим). На нашу думку, причиною подібного явища може бути значна ступінь тінізації економіки України (так, за оцінкою Мінекономрозвитку, у 2014 році рівень тіньової економіки в Україні склав 43\% ВВП), окремим проявом якої $\epsilon$ заниження досліджуваних статистичних показників. 3 метою збільшення достовірності розрахунків пропонуємо здійснити коригування наявних статистичних даних за допомогою коефіцієнту тінізації економіки, при цьому вихідні значення кількості туристів прийматимуться за $100 \%$. Оскільки існують декілька методик розрахунку ступеню тінізації, які застосовуються переважно для окремих спеціалізованих галузей економіки, для більшої правильності розрахунків візьмемо інтегральний коефіцієнт тінізації економіки України. Статистичні дані щодо кількості медичних туристів у 2011-2017 pp. 3 урахуванням коефіцієнту тінізації економіки наведено у табл. 3. Варто відзначити, що під час розрахунків дані коригувалися із врахуванням значення коефіцієнту тінізації економіки для кожного року, дані за який приймають

Вісник економіки транспорту і промисловості № 63, 2018 
участь в розрахунках, що дозволило отримати більш точні результати розрахунків.

На основі розрахованих у таблиці 2 даних побудуємо графіки із подальшим здійсненням поліноміального тренданалізу. Результати наведені на рис. 6.

Таблиия 3

Кількість медичних туристів у 2011-2017 рр. з урахуванням коефіиієнту тінізації економіки [10,11]

\begin{tabular}{|l|l|l|l|l|l|l|l|}
\hline Рік & 2011 & 2012 & 2013 & 2014 & 2015 & 2016 & 2017 \\
\hline $\begin{array}{l}\text { Коефіцієнт тінізації, } \\
\text { \% від ВВП }\end{array}$ & 34 & 34 & 35 & 43 & 40 & 34 & 33 \\
\hline До України & 20829 & н/д & н/д & н/д & 3398 & 7923 & 4002 \\
\hline З України & 3897 & н/д & н/д & н/д & 1606 & 1968 & 12463 \\
\hline
\end{tabular}

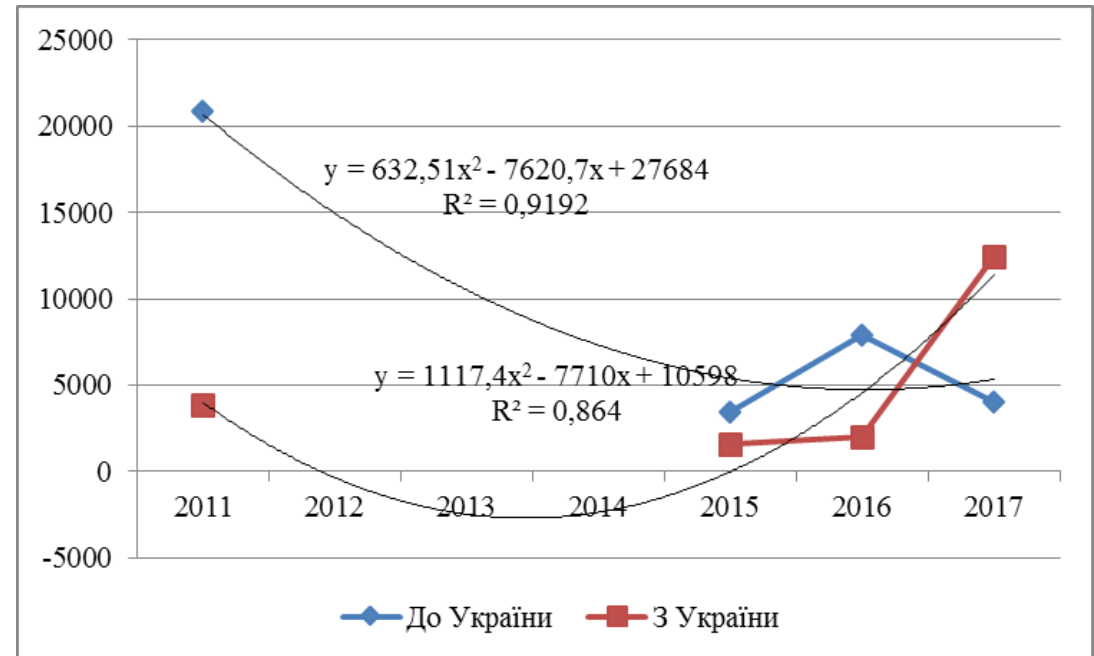

Рис. 6. Поліноміальний тренд-аналіз динаміки кількості медичних туристів до Украӥни та з Украӥни з урахуванням коефіцієнту тінізації економіки

Як можна побачити на рис. 6, характер побудованих графіків та ліній тренду не змінився, коефіцієнт детермінації $\mathrm{R}^{2}$ також залишився незмінним. Це означає, що коригування даних за допомогою коефіцієнту тінізації не позбавило нас від проблеми від'ємних значень даних у ряді «3 України», на наявність яких вказує лінія тренду. На нашу думку, причиною збереження даного явища може бути використання недостовірних даних при розрахунках або недоліки обраної моделі досліджень. Беручи до уваги той факт, що статистичні дані були взяті з офіційного джерела, ми робимо висновок про те, що саме недосконалість моделі досліджень є причиною виникнення можливих від'ємних значень досліджуваних величин, тому виникає необхідність змінити підхід до дослідження. Враховуючи, що досліджуваний період часу складає 7 років (iз 2011 по 2017 рр.), причому за 2012-2014 роки дані відсутні, можна припустити, що використання поліноміального тренду 2 порядку (який дозволяє знайти один максимум або мінімум впродовж усього періоду) не $\epsilon$ достатнім, і лінія тренду може мати більше одного екстремуму. Тому ми проведемо поліноміальний тренд-аналіз вищого порядку, перед цим за допомогою графіків знайшовши приблизні значення величин туристичних потоків до України с та з України за 2012-2014 роки. В якості 
основи візьмемо графіки, побудовані на рис. 3. Після цього на основі цих даних розрахуємо кількість туристів, що прибули до України у 2012-2014 pp., із урахуванням тінізації економіки (оскільки кількість туристів, що виїхали з України за даний період, за наявними розрахунками має від'ємні значення, для неї коригування проводити не будемо). Дані наведені у таблиці 4.

Таблиця 4

Кількість медичних туристів у 2011-2017 рр. з урахуванням коефіиієнту тінізації економіки $[9,11]$

\begin{tabular}{|l|l|l|l|l|l|l|l|}
\hline Рік & 2011 & 2012 & 2013 & 2014 & 2015 & 2016 & 2017 \\
\hline До України & 15544 & 11040 & 7680 & 5440 & 2427 & 5913 & 3009 \\
\hline 3 України & 2908 & -320 & -1950 & -1840 & 1147 & 1469 & 9371 \\
\hline $\begin{array}{l}\text { Коефіцієнт тінізації, } \\
\text { \% від ВВП }\end{array}$ & 34 & 34 & 35 & 43 & 40 & 34 & 33 \\
\hline $\begin{array}{l}\text { До України } \\
\text { коефіцієнтом } \\
\text { тінізації) }\end{array}$ & 20829 & 14794 & 10368 & 7779 & 3398 & 7923 & 4002 \\
\hline $\begin{array}{l}3 \quad \text { України } \\
\text { коефіціснтом } \\
\text { тінізації) }\end{array}$ & 3897 & н/д & н/д & н/д & 1606 & 1968 & 12463 \\
\hline
\end{tabular}

3 метою оцінки точності проведених розрахунків побудуємо графіки, що відображають кількість туристів, що прибули до України з метою лікування у 2011-2017 роках, із урахуванням та без урахування коефіцієнту тінізації економіки України, здійснимо їх тренд-аналіз та порівняємо отримані результати із попередніми розрахунками. Результати наведені на рис. 7.

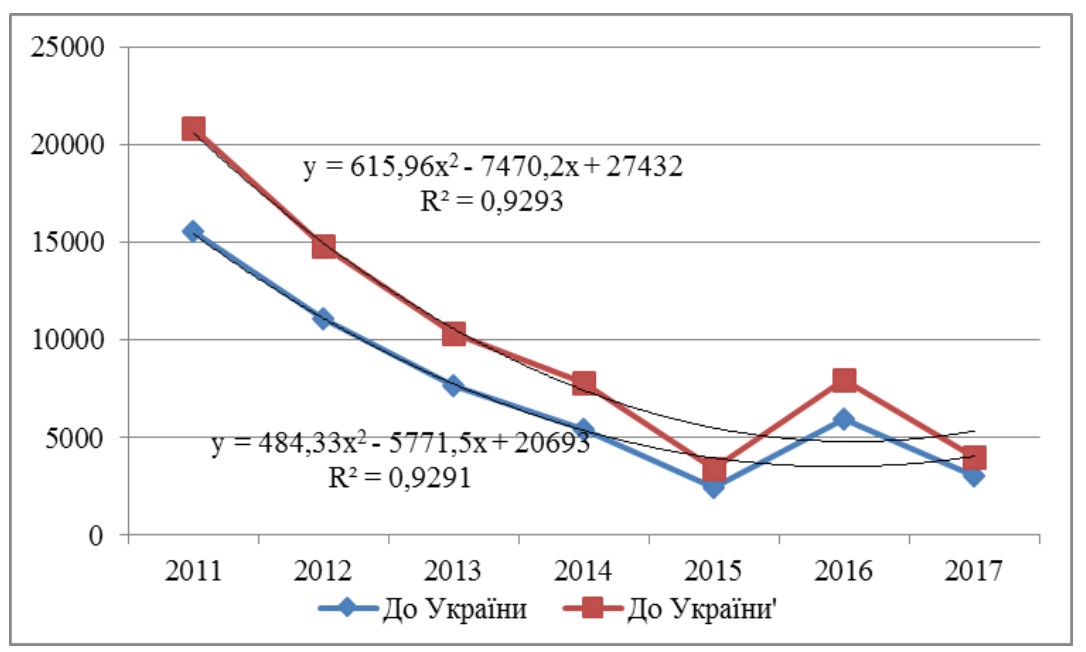

Рис. 7. Порівняння динаміки вхідних потоків медичних туристів за 2011-2017 р. $з$ урахуванням та без урахування тінізації економіки

Вивчивши отримані графіки, ми можемо помітити, що вони мають подібну динаміку, значення мінімуму та практично однакові значення коефіцієнту детермінації
$\mathrm{R}^{2}$. Різна ступінь нахилу ліній тренду, на нашу думку, зумовлена саме величиною значень за 2011 рік, оскільки значення досліджуваної величини в цьому році $\epsilon$ 
найбільшим за весь період, тому при коригуванні кількості туристів за допомогою коефіцієнту тінізації економіки зміна цієї величини буде найбільшою.

Тепер порівняємо лінії тренду на рис. 7 із отриманими раніше. Так, рівняння тренду для вхідного потоку туристів без урахування тінізації економіки без даних за 2012-2014 р. має вигляд $y=485,79 x 2$ $5790,6 x+20748, \mathrm{R}^{2}=0,9171$. Для цього ж потоку з урахуванням даних за 2012-14 pp. рівняння тренду становить $y=484,33 x 2$ $5771,5 x+20693$, а коефіцієнт детермінації $\mathrm{R}^{2}$ дорівнює 0,9291. Можна побачити, що значення усіх коефіцієнтів $є$ приблизно однаковим, на основі чого ми робимо висновок про достовірність зроблених розрахунків. Тепер порівняємо лінії тренду для вхідних потоків туристів із урахуванням коефіцієнту тінізації економіки України. Рівняння тренду без даних за 2012-2014 рр. має вигляд $y=$
$632,51 x 2-7620,7 x+27684$ із коефіцієнтом $\mathrm{R}^{2}=0,9192$, в той час як дані за увесь період 2011-2017 pр. описані рівнянням тренду $y=615,96 x 2-7470,2 x+27432, \mathrm{R}^{2}=$ 0,9293. В цьому випадку також спостерігається близькість значень коефіцієнтів перед змінними, а також значень коефіцієнту детермінації даних рівнянь, що, на нашу думку, також підтверджує правильність проведених розрахунків.

Тепер здійснимо тренд-аналіз третього порядку для вхідного та вихідного потоків медичних туристів. В цьому випадку рівняння тренду матиме вигляд $y=a x^{3}+b x^{2}+c x+d$, що дасть нам можливість виявити додатковий екстремум на лінії тренду цього ряду даних. 3 метою досягнення більшої точності розрахунків візьмемо дані з урахуванням коефіцієнту тінізації економіки. Результати наведені на рис. 8 .

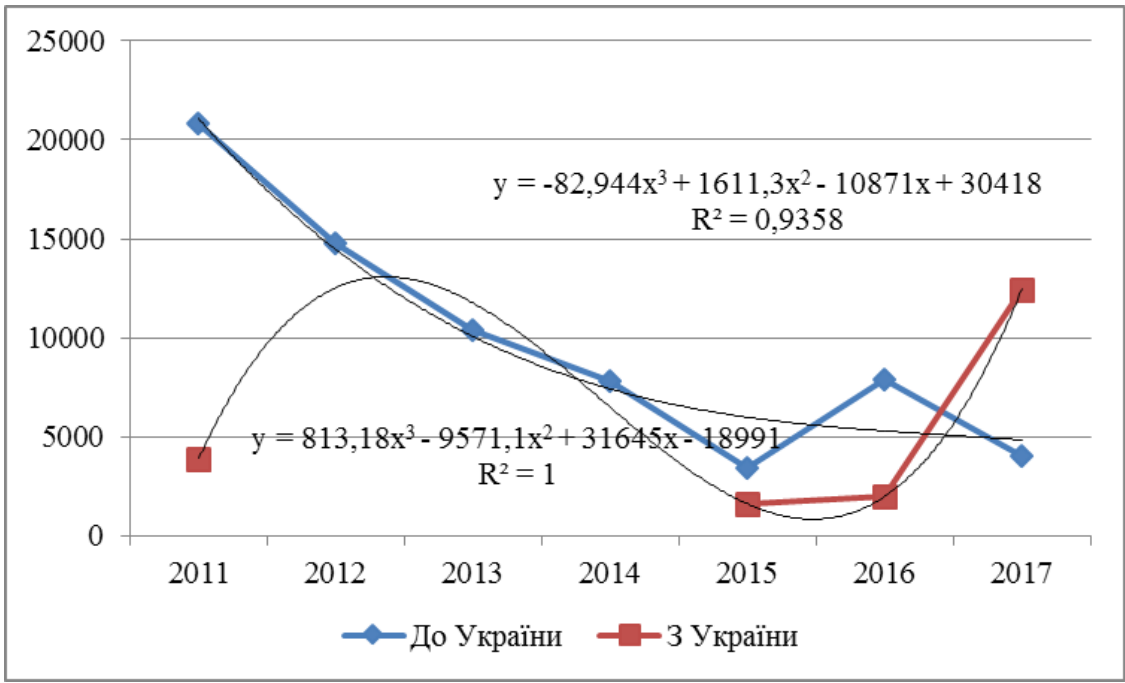

Рис. 8. Поліноміальний тренд-аналіз третього порядку для досліджуваних потоків туристів у 2011-2017 рр.

Дослідимо отримані результати. Рівняння тренду для потоку «До України» має від'ємний нахил i коефіцієнт детермінації $\mathrm{R}^{2}=0,9358$. В свою чергу, рівняння потоку «З України» має вигляд $y$ $=813,18 x 3-9571,1 \times 2+31645 x-18991$ та коефіцієнт $\mathrm{R}^{2}$ у цьому випадку дорівнює 1. Це може означати наявність функціональної залежності, враховуючи відсутність фактичних даних та їх можливу неточність, a також наявність гетероскедастичності, ми не можемо стверджувати про іiі наявність. Характер використовуваних даних дає нам змогу зробити припущення про присутність статистичної похибки. Окрім того, з'явився максимум на лінії тренду проте, між позначками 2012 та 2013 рр. (даний 
максимум, на нашу думку, є локальним, оскільки після 2017 р. лінія тренду через високе значення туристів 3 України в цьому році при збереженні тенденції до зростання їх кількості може піднятися вище рівня 2012 року). Тепер, користуючись рис. 8, знайдемо значення кількості медичних туристів з України у 2012-2014 роках з урахуванням тінізації економіки, після чого розрахуємо їх первинне значення, поділивши отримані дані на коефіцієнт тінізації економіки для кожного окремого року. Результати наведені у табл. 5.

Таблиия 5

Кількість медичних туристів у 2011-2017 рр. з урахуванням та без урахування коефічієнту тінізачії економіки (розраховано за тренд-аналізом третього порядку) [10]

\begin{tabular}{|l|l|l|l|l|l|l|l|}
\hline Рік & 2011 & 2012 & 2013 & 2014 & 2015 & 2016 & 2017 \\
\hline До України & 15544 & 11040 & 7680 & 5440 & 2427 & 5913 & 3009 \\
\hline 3 України & 2908 & 8178 & 7630 & 3718 & 1147 & 1469 & 9371 \\
\hline $\begin{array}{l}\text { Коефіцієнт } \\
\text { тінізації, \% } \\
\text { від ВВП }\end{array}$ & 34 & 34 & 35 & 43 & 40 & 34 & 33 \\
\hline До України’ & 20829 & 14794 & 10368 & 7779 & 3398 & 7923 & 4002 \\
\hline 3 України’ & 3897 & 12391 & 11739 & 6522 & 1606 & 1968 & 12463 \\
\hline
\end{tabular}

За отриманими в результаті здійснимо поліноміальний тренд-аналіз розрахунків значеннями кількості третього порядку. Результати наведені на медичних туристів (без урахування рис. 9. тінізації економіки) складемо графік i

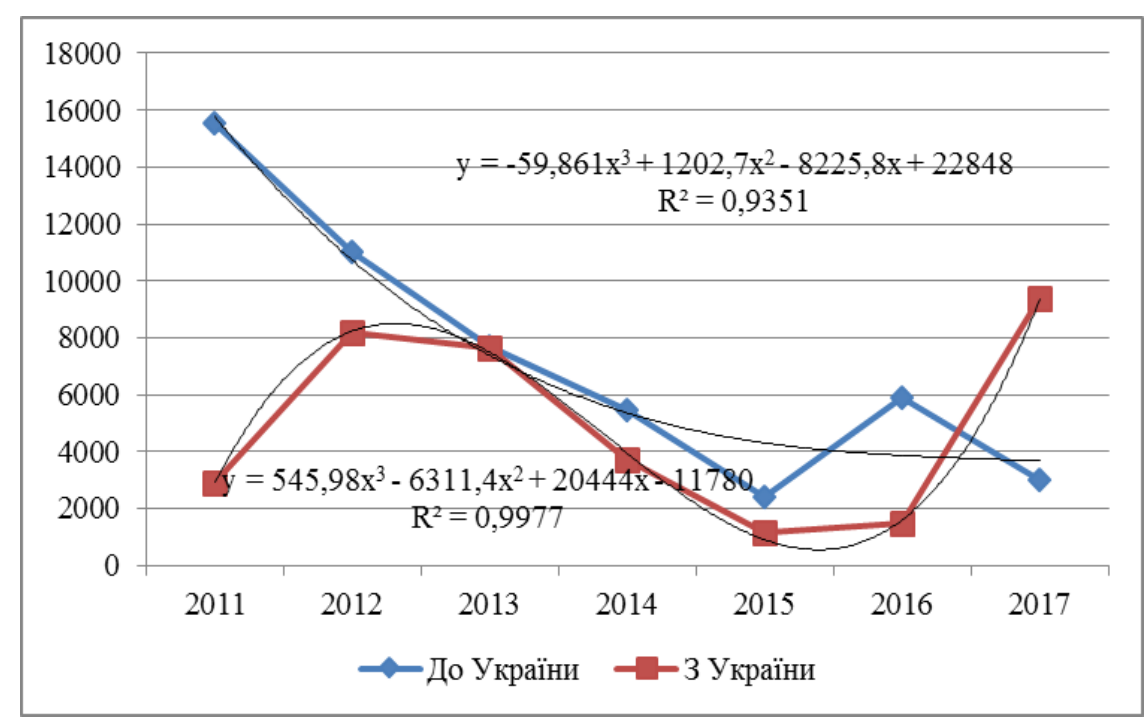

Рис. 9. Поліноміальний тренд-аналіз третього порядку для досліджсуаних потоків туристів у 2011-2017 рр. (без урахування коефіцієнту тінізаџії економіки)

Висновки. Аналіз досліджуваних переважання туристів, що прибувають до величин показує, що для галузі медичного України 3-за кордону (хоча в 2017 році туризму України за досліджуваний становище змінилося). При цьому кількість проміжок часу в цілому характерним $€$ закордонних медичних туристів виявляє 
тенденцію до падіння, в той час як кількість українців, що відправляється на лікування за кордон, має більш нестабільну динаміку, проте за останні 2 роки вона стрімко зросла, досягнувши максимального значення у 9371 осіб в 2017 році. На нашу думку, подібне становище галузі може бути спричинене змінами економікополітичного становища в Україні, яке $\epsilon$ важливим фактором впливу на економіку країни в цілому та, зокрема, на стан туризму в країні. Так, можна побачити, що кількість закордонних туристів (яка в цілому виявляє тенденцію до спаду) скоротилася дещо сильніше після 2014 року, коли спалахнув конфлікт на сході України. В 2016 році вона вперше виросла, сягнувши другої за величиною позначки у 5913 осіб, проте в наступному році вона знову впала. Що стосується потоку медичних туристів з України, можна побачити, що у випадку з ним залежність від економіко-політичного стану простежується більш чітко. Так, ріст кількості туристів з України спостерігався з 2011 по 2012 рр., коли значні економічні проблеми та політичні зміни були відсутні. Починаючи з 2013 року, спостерігається скорочення кількості медичних туристів 3 України, що може бути спричинене подіями 2013-2014 p., в тому числі конфліктом на сході України та погіршенням відносин із Російською Федерацією. Після 2015 р., коли ситуація в країні відносно стабілізувалася, спостерігався незначний ріст даного потоку туристів. Найбільше осіб виїхало 3 України на лікування у 2017 році, що може бути зумовленим встановленням безвізового режиму із СС у червні. Цьому, на нашу думку, може також сприяти медична реформа 2018 року, яка може створити перешкоди для отримання медичної допомоги не лише для українців, але i для іноземних громадян. Втім, маючи значні можливості для приваблення іноземних пацієнтів та здійснюючи раціональну політику в сфері медицини, економіки та туризму, Україна має шанси стати одним із основних центрів медичного туризму як на регіональному, так і на міжнародному рівні.

\section{ПЕРЕЛІК ВИКОРИСТАНИХ ДЖЕРЕЛ}

1. Баранов Д.Н. Современные тенденции развития экономики городских агломераций: монография [Электронный ресурс] / Д.Н. Баранов. - Саратов: Вузовское образование, 2015. 188 с. Режим доступа: http://www.iprbookshop.ru/33855

2. Краснолободцев А.А. Психологическое измерение эффективности феномена «бренд» // Международный журнал. Социальноэкономические явления и процессы. 2009. №4. C. 107.

3 . Безрутченко, Ю.В. Маркетинг в социально-культурном сервисе и туризме: Учебное пособие / Ю.В. Безрутченко. - М.: Дашков и К, 2012. - 232 с.

4. Смирнов І.Г. Логістика туризму: Навч. посібник. - К.: Знання, 2009. 444c.

5. Corruption Peecseption Index 2013 [Электронный ресурс] // Режим доступа: http://cpi.transparency.org/cpi2013/results/

6. Doing Business - Рейтинг экономик [Электронный ресурс] // Режим доступа:

http://russian.doingbusiness.org/Rankings

7. Dordevic M., Kokic Arsic A. Tourism logistic system - conceptual consideration // 4 international quality conference center for quality. University of Kragujevac. - Serbia, 2010. - p. 57-62.

9. Офіційний сайт Міністерства економічного розвитку i торгівлі: [Електронний ресурс]. - Режим доступу::http://www.iso.org/iso/home/standar ds/certification/iso-survey.htm?certificate =IShttp://www.me.gov.ua/Document s/Detail?lang

10. В ООН підрахували кількість туристів у світі. [Електронний ресурс]. Режим доступу:https://nachasi.com/2018/01/16/kilkis t-turystiv-u-sviti/

11. В мире быстро растет число 
туристов - WTTC [Електронний ресурс]. - mire-bystro-rastet-chislo-turistov-wttcРежим доступу: 1065963.html

https://www.segodnya.ua/economics/enews/v-

DOI 10.18664/338.47:338.45.v\%vi\%i.146148

УДК 339.187.6

\title{
ОРЕНДА ТА ЛІЗИНГ -СКЛАДОВІ ЕЛЕМЕНТИ РИНКОВОЇ ЕКОНОМІКИ
}

\author{
Кірдіна О.Г., д.е.н., професор, \\ Дацковська Д.О., махістр (УкрДУЗТ)
}

В статті розглядається украӥнський ринок лізингу, який досі займає дуже малу частку в обсягах фінансування економіки в порівнянні з кредитом, але має значний потенціал саме в украйнських реаліях. Все менше доводиться пояснювати потенційним лізингоодержувачам, щуо таке лізинг $і$ чим він відрізняється від кредиту. Питання $з$ орендою виникає рідше. Але коли вже виникає, то відповідно вимагає відповіді.

Ключові слова: оренда, лізинг, рейтинг, хайринг, ціноутворення, орендодавець, лізингоодержувач, ціноутворення, конкурентні переваги.

\section{АРЕНДА И ЛИЗИНГ - СОСТАВЛЯЮЩИЕ ЭЛЕМЕНТЫ РЫНОЧНОЙ ЭКОНОМИКИ}

\author{
Кирдина Е.Г., д.э.н., профессор, \\ Дацковская Д.А., магистр (УкрГУЖДТ)
}

В статье рассматривается украинский рынок лизинга, который до сих пор занимает очень маленькую часть в обьемах финансирования экономики по сравнению с кредитом, но имеет существенный потенциал именно в украинских реалиях. Все менше приходиться объяснять потенииальным лизингополучателям, что такое лизинг и чем отличается от кредита. Вопрос с арендой возникает реже. Но когда уже возникает, то соответственно требует ответа.

Ключевые слова: аренда, лизинг, рейтинг, хайринг, ценообразования, арендодатель, арендатор, ценообразования, конкурентные преимущества.

\section{LEASE AND LEASING - COMPONENTS OF MARKET ECONOMICS}

\author{
Kirdina E.G., doctor of Economics, Professor, \\ Datskovskaya D.A., master (USURT)
}

The article considers the Ukrainian leasing market, which still occupies a very small part in the volumes of financing the economy in comparison with the loan, has a significant potential precisely in Ukrainian realties. It is less and less necessary to explain to potential

(C) Кірдіна О.Г., Дацковська Д.О.

Вісник економіки транспорту і промисловості № 63, 2018 